\title{
Dasar dasar pengambilan keputusan dalam keperawatan Indah Pandiangan
}

indahpandiangan@gmail.com

\section{Latar belakang}

Berpikir merupakan suatu kemampuan manusia dan bersifat kodrati yang diberikan olah Tuhan Yang Maha Esa. Kita sebagai manusia dewasa sudah berhak untuk memikirkan dan membedakan mana tindakan yang baik dan mana pula tidakan yang buruk. Sudah relatif baguskah sebuah keputusan yang kita putuskan? Atau malah sebaliknya.Kemampuan berpikir kritis dan kreatif merupakan kemampuan yang sangat esensial untuk kehidupan, pekerjaan, dan berfungsi efektif dalam semua aspek kehidupan lainnya. Penelitian dan berbagai pendapat tentang hal itu, telah menjadi topik pembicaraan dalam sepuluh tahun terakhir ini bahwa berpikir kritis banyak dikemukakan para ahli. Perawat sebagai bagian dari pemberi layanan kesehatan, yaitu memberi asuhan keperawatan dengan menggunakan proses keperawatan akan selalu dituntut untuk berfikir kritis dalam berbagai situasi baik itu dalam menentukan keputusan untuk sebuah tindakan maupun untuk sebuah saran kepada pasien secara kontiniu. Penerapan berfikir kritis dalam proses keperawatan dengan kasus nyata yang akan memberikan gambaran kepada perawat tentang pemberian asuhan keperawatan yang komprehensif dan bermutu. Seseorang yang berfikir dengan cara kreatif akan melihat setiap masalah dengan sudut yang selalu berbeda meskipun obyeknya sama, sehingga dapat dikatakan, dengan tersedianya pengetahuan baru, seseorang profesional harus selalu melakukan sesuatu dan mencari apa yang selalu efektif dan ilmiah serta memberikan hasil yang lebih baik untuk kesejateraan diri maupun orang lain. Perawat dengan pemikiran yang kreatif akan menunjang seluruh aspek asuhan keperawatannya secara efektif dan terampil. Selain itu pula perawat mampu melakukan suatu keputusan dengan tanggap dan cepat dengan menggunakan metode berfikir kritis. Melalui sudut pandangnya yang berbeda-beda itu juga lah yang dapat menunjang produktivitas nya dalam melakukan intervensi keperawatan.

\section{Tujuan}


Untuk mengetahui proses dan model-model pengambilan keputusan dengan konsep berfikir kritis agar dapat meningkatkan kemampuan dan ketrampilan perawat dalam pengambilan keputusan. Pengambilan keputusan tidak dilakukan secara sembrono tapi harus berdasarkan pada sistematika tertentu. Keputusan yang baik adalah keputusan yang telah dipilih dari berbagai alternatif yang telah dianalisa secara matang. Pengambilan keputusan ini bertujuan untuk memilih pilihan yang tepat agar mencapai hasil yang terbaik sesuai kondisi dan prioritas masalah klien.

\section{Metode}

Metode yang digunakan pada kajian ini adalah metode kualitatif yang memberikan penjelasan dengan menggunakan analisis pada referensi-refensi yang digunakan. Jurnal ini menggunakan metode referensi melalui jurnal-jurnal yang terkait dengan pengambilan keputusan perawat dengan menggunakan metode Critical Thinking. Penggunaan metode ini mengangkat judul mengenai dasar pengambilan keputusan perawat dengan metode chritical thinking atau berpikir secara kritis, efektif dan sistematis. Jurnal ataupun literatur ini tidak melalui studi penelitian ataupun observasi kepada pihak yang terkait terhadap implementasi pengambilan keputusan cepat perawat secara nyata maupun real. Literatur ini hanya memaparkan penjelasan secara jelas berupa penggambaran pengambilan keputusan tindakan dengan metode bepikir kritis pada individu mengenai tahap - tahap pengambilan keputusan.

\section{Hasil}

lima faktor yang menjadi dasar bagi perawat berpikir kritis untuk mengambil keputusan tindakan keperawatan.

Pertama yaitu membaca dengan kritis. Kita sebagai perawat harus dapat membaca dengan kritis semua informasi terkait kondisi pasien dengan cara yang sistematis

Kedua yaitu menulis dengan kritis terkait dengan dokumentasi pasien dengan pemahaman dan penalaran yang adekuat. Dokumentasi tersebut merupakan salah satu tolak ukur untuk menuangkan seluruh aspek asuhan yang akan diberikan kepada pasien dan dapat menjadi acuan untuk asuhan yang selanjutnya. 
Ketiga adalah mencoba untuk menganalisis dari apa yang kita baca dan kita tulis. Melalui hal hal yang kita tulis tersebut, kita dapat mendiskusikan apa saja bahan yang telah kita kumpulkan untuk memecahkannya secara bersama (team working)

Keempat adalah mengembangkan kemampuan observasi. Dengan adanya observasi atau mengamati suatu kondisi klien akan memudahkan seorang profesi perawat untuk menarik kesimpulan dari kondisi klien yang diamati. Menganalisis disini dapat menjadi acuan dalam mengambil keputusan.

Kelima adalah mengembangkan kemampuan dalam pertanyaan yang bermutu guna meningkatkan kemampuan perawat dalam berpikir untuk menguras kembali ilmunya yang telah ia pelajari.

\section{Pembahasan}

\section{BERPIKIR KRITIS}

\section{A. Pengertian Berpikir Kritis}

Berpikir kritis merupakan seni gambaran sikap seseorang dalam menganalisis, mengevaluasi sesuatu yang ia lihat, mengklarifikasi yang di dengar, metode pengetahuan untuk berfikir logis dan berargumen serta aplikasi dari ilmu yang dipahami untuk membuat suatu keputusan dan memutuskan sesuatu setelah hal tersebut ia yakini, Berpikir kritis sangat dibutuhkan oleh siapa saja yang menyandang profesi sebagai nurse atau pun perawat.

Berpikir kritis sangat dibutuhkan dan sudah sepantasnya mahasiswa keperawatan dibekali hal tersebut karena sangat berkaitan dan bersinggungan dengan pengambilan keputusan. Kepandaian berpikir kritis dalam dunia keperawatan sangatlah dibutuhkan, karena untuk pemecahan suatu masalah (problem solving) bagi seorang perawat sangat berkaitan erat terkait keputusan dan tindakan yang akan ia ambil, melalui sudut padang serta latar belakang yang berbeda. Melalui berpikir kritis perawat diasah untuk meningkatkan kemampuan verbal dan analitik meningkatkan kemampuan verbal dan analitik yang sistematis sehingga mengeksplorasikan gagasan - gagasan, menganalisis masalah hingga memahami masalah khususnya dalam bidang keperawatan. Berpikir kritis meningkatkan kreatifitas. Untuk menghasilkan solusi kreatif terhadap suatu masalah tidak hanya memerlukan gagasan baru namun dengan berpikir kritis dapat mengevaluasi gagasan lama dan baru, memilih yang terbaik 
dan memodifikasi bila perlu. Perawat sebagai praktisi maupun dalam pendidikan harus menggunakan unsur-unsur dasar dalam berpikir kritis agar asuhan keperawatan yang akan diberikan berkualitas.

\section{B. Unsur - Unsur Dasar dalam Asuhan Keperawatan}

Unsur pertama dalam berpikir kritis adalah konsep. Seorang perawat harus memahami konsep dasar asuhan keperawatan, konsep - konsep dasar kebidanan baik definisi, aturan yang mengikat atau etika profesi dan prinsip - prinsip dari konsep keperawatan tersebut. Agar tidak salah tindakan untuk memberikan intervensi keperawatan. Kita sebagai profesi perawat harus memahami dasar dari kronologi keluhan pasien agar dapat memberikan intervensi yang baik dan optimal.

Unsur kedua adalah asumsi, yaitu dugaan sementara oleh perawat terhadap kasus keperawatan yang ditangani. asumsi akan menjadi diagnosa nyata setelah perawat melakukan pengumpulan data subjektif dan objektif secara akurat dan diolah dengan berpikir kritis, analisis dan logis. Peningkatan daya analisis perawat sangat dibutuhkan disini, dikarenakan perawat harus berpikir secara menyeluruh, kritis dan logis dikarenakan perawat harus menganalisis kasus keperawatan yang datang.

Unsur Ketiga adalah implikasi dan konsekuensi. Perawat melakukan suatu tindakan dan bertanggungjawab untuk setiap konsekuensi yang timbul dari masingmasing tindakan yang telah dilakukan karena setiap tindakan memiliki alasan atau rasionalnya. Maka dari itu, kita sebagai perawat tidak dibenarkan untuk lepas tanggung jawab terkait asuhan yang baru saja kita berikan kepada pasien. Bisa saja sewaktu - waktu pasien menolak dikarenakan implikasi yang diberikan salah atau tidak sesuai dengan aturan yang tertera pada SOP ( Standart Operasional Prosedure ).

Unsur Keempat adalah tujuan. Asuhan keperawatan harus jelas tujuan dan rasional. Harus jelas tindakan apa sajakan yang akan diberikan kepada pasien dan perawat selalu menghargai pasien apapun permintaan dan keputusan yang diajkukannya.

Unsur Kelima adalah pertanyaan atas isu yang ada. Perawat dalam melakukan asuhan keperawatan harus memecahkan semua pertanyaan atau isu yang ada. Kita seharusnya memberikan informasi kepada pihak keluarga yang bersangkutan dikarena kan salah satu 
pelayanan keperawatan yang dapat diberikan perawat yaitu memberi informasi kesehatan kepada keluarga dan pasien terkait hal - hal yang tidak diketahui pasien tersebut. Unsur

keenam adalah informasi akurat, yaitu asuhan keperawatan harus didapat dari data yang akurat, jelas sumber, fakta ataupun melakukan observasi langsung. Informasi tersebut diharuskan berasal dari data yang jelas dan akurat, menyangkut kepada data objektif dan data subjektif. Informasi tersebut haruslah dipandang dan dinilai dari penggunaan berpikir kritis, selain itu pula informasi tersebut harus disandingkan dengan pemeriksaan yang di lakukan kembali oleh perawat terkait dengan keluhan yang di keluhkan pasien.

Unsur ketujuh adalah interpretasi dan inferensi. Asuhan keperawatan akan memberikan hasil akhir sehingga dapat mengambil keputusan terhadap asuhan keperawatan yang diberikan. Bagian inilah yang sangat penting dan puncak dari berpikir kritis. Bagian ini yang dapat kita asuhkan kepada pasien setelah melewati 6 point diatas. Kreatifitas dalam berpikir kritis merupakan proses menemukan sesuatu yang baru dan memerlukan suatu rangsangan dari lingkungan.

Sebagai perawat dinyatakan berpikir kreatif jika seorang perawat mampu menemukan hal baru dengan mempertimbangkan manfaat, tujuan dan melahirkan atau menata kembali ide yang lama membentuk suatu ide yang baru. Kualitas suatu pelayanan dapat dinilai dengan cara bagaimana seorang profesi keperawatan tersebut memberikan suatu asuhan yang sistematis dan komprehensif, suhan keperawatan yang tepat guna, sesuai dengan masalah dan kebutuhan dari kondisi klien. Untuk tercapainya ini semua, maka sebagai seorang profesi perawat harus mampu menganalisis dan menggunakan pikiran untuk kritis disetiap langkah kegiatan asuhan. Seorang perawat yang professional harus memiliki karakteristik dalam berpikir kritis.

Hal ini meliputi seorang perawat mampu mempertimbangkan sesuatu sesuai dengan alasan yang rasional dan logis, bersifat reflektif, mampu menganalisis, mensintesis, mengevaluasi buktibukti yang ada terkait masalah yang akan dipecahkan, memiliki kemampuan pemecahan masalah (problem solvig). Karakteristik lainnya menurut beberapa ahli adalah seorang perawat mampu membuat suatu kesimpulan dari berbagai informasi yang diperoleh, dari berbagai hasil pemeriksaan yang telah dikumpulkan dengan adanya bukti, membuat argument yang beralasan untuk mendukung kesimpulan dan menjelaskan pola fikir yang telah terbentuk dari hasil kegiatan langkah-langkah karakteristik sebelumnya. 


\section{DASAR CARA MENGAMBIL KEPUTUSAN DENGAN METODE BERPIKIR KRITIS DALAM ASUHAN KEPERAWATAN}

Cara untuk meningkatkan kemampuan berpikir kritis diantaranya :

Cara pertama adalah membaca dengan kritis. Untuk berpikir secara kritis, seorang profesi perawat harus bisa membaca dengan kritis pula. Semua informasi yang didapat dari berbagai sumber harus dipikirkan secara kritis, disesuaikan dengan kondisi klien disaat memberikan suatu asuhan. Membaca kritis berarti menerapkan keterampilan - keterampilan berpikir kritis seperti mengamati, menghubungkan teks dengan konteksnya, mengevaluasi teks dari logika dan kredibilitasnya, merefleksika kandungan teks dengan pendapat sendiri dan membandingkan tes yang satu dengan yang lainnya yang memiliki keterkaitan.

Cara kedua adalah menulis dengan kritis. Seorang profesi perawat yang telah melakukan membaca dengan kritis harus menuliskan semua pemahaman yang ada dalam bentuk tulisan. Salah satu contohnya adalah dokumentasi dalam asuhan keperawatan. Dokumentasi tersebut merupakan suatu media bagi profesi perawat untuk menuangkan semua asuhan yang telah diberikan dan menjadi acuan untuk asuhan berikutnya.

Cara ketiga adalah meningkatkan analisis dari yang dibaca dan ditulis. Asuhan keperawatan yang telah dituliskan dapat menjadi bahan diskusi untuk dievaluasi atau mencari penyelesainan masalah atau mendiskusikan hal terburuk yang mungkin terjadi.

Cara keempat adalah mengembangkan kemampuan observasi. Observasi atau mengamati suatu kondisi klien akan memudahkan seorang profesi perawat untuk menarik kesimpulan dari kondisi klien yang diamati. Pengamatan tersebut dikritisi dan pengamatan yang ia dapatkan bisa menjadi acuan untuk menarik kesimpulan yang berdampak pada pembuaan keputusan.

Cara kelima yaitu meningkatkan rasa ingin tahu, kemampuan bertanya dan refleksi.Pengajuan pertanyaan yang bermutu yaitu pertanyaan yang tidak memiliki jawaban benar atau salah atau pertanyaan yang mengharuskan seorang profesi perawat menjelaskan sehingga memperbanyak berpikir.

\section{Penutup}


disimpulkan bahwa, terdapat lima faktor yang menjadi teknik atau cara dalam mengambil keputusan perawat untuk melakukan intervensi keperawatan yaitu diantaranya membaca dengan kritis, menulis dengan kritis terkait dengan dokumentasi pasien, mencoba untuk menganalisis hal - hal apa yang yang menjadi kendala pasien dan di diskusikan, mengembangkan kemampuan observasi untuk menarik kesimpulan dari kondisi pasien, dan mengembangkan kemampuan tersebut.

\section{Daftar pustaka}

1. Simamora, R. H. (2019). Menjadi perawat yang: CIH'HUY. Surakarta: Kekata Publisher.

2. Simamora, R. H. (2005). Hubungan Persepsi Perawat Pelaksana Terhadap Penerapan Fungsi Pengorganisasian Yang Dilakukan Oleh Kepala Ruangan Dengan Kinerjanya Diruang Rawat Inap RSUD Koja Jakarta Utara (Doctoral dissertation, Tesis FIK UI, Tidak dipublikasikan).

3. Bandiyah, Siti. (2017). Ketrampilan Dasar Keperawatan. Yogyakarta: Nuha Medika

4. Deniati, dkk. (2018). Pengaruh Berfikir Kritis Terhadap Kemampuan Perawat Pelaksana Dalam Melakukan Asuhan Keperawatan di Rumah Sakit Hermina Bekasi Tahun 2016. Jurnal Kesehatan Holistik, 12(1), 21-24

5. Haryanto, A. (2014). Hubungan Berfikir Kritis dan Waktu Tanggap Perawat dengan Kualitas Asuhan Keperawatan di Instalasi Gawat Darurat Rumah Sakit Islam Surabaya. Jurnal Sebelas Maret

6. Heni. (2017). Berfikir Kritis Dalam Proses Keperawatan. Jurnal Keperawatan, 3(1), 2629

7. Kowiyah. (2012). Kemampuan Berfikir Kritis. Jurnal Pendidikan Dasar, 3(5), 175-178

8. Sudono, dkk. (2017). Gambaran Kemampuan Berfikir Kritis Perawat Primer Dalam Pelaksaan Asuhan Keperawatan di Rumah Sakit Islam Surakarta. Jurnal Ilmu Keperawatan Indonesia, 10(1), 81-84

9. Sumijatun. (2009). Konsep Dasar dan Aplikasi Pengambilan Keputusan Klinis. Jakarta: Trans Info Media Jakarta 10. Sudono, B, dkk. (2017). Jurnal Ilmu Keperawatan Indonesia Vol. 10, No. 1 11. Ayu N., Jurnal Kesehatan Holistik. (2018). Vol 12, No. 1 
12. Amanda, A, dkk. (2015). Konsep Berpikir Kritis dan Pengambilan Keputusan dalam Keperawatan Serta Perumusan Diagnosis. Jakarta : Universitas Indonesia 